\title{
A multidimensional approach to the analysis of perceived value in tourism
}

\author{
Snežana Topalović ${ }^{1 *}$, Veljko Marinković ${ }^{1}$ \\ ${ }^{1}$ University of Kragujevac, Faculty of Economics, Kragujevac, Serbia
}

\begin{abstract}
The key to achieving business goals is based on both understanding and comprehending how consumers perceive a service offering and exploring the elements that determine cus tomer satisfaction and loyalty. Modern tourismenterprises should focus on creating and delivering value to their consumers as a significant source of competitive advantage. The aim of this paperis to identify the dimensions of the service offer values of the travel agencies in which there are significant differences in the ratings of the female and male respondents. To meet the res earch objectives, a $t$-test for two independent samples was used. Field research was conducted and primary data were collected by the survey method. This paper seeks to show that value for service users is a complex and multidimensional concept. Tourism services can be better perceived and understood if they are analysed through a multidimensional approach to value, as users of tourism services can at the same time experience and enjoy functional, social, emotional and other factors. The paper presents different approaches to the analysis of perceived value that are present in the world marketing literature and which form the basis for conception of future research.
\end{abstract}

Keywords: perceived value, value dimensions, multidimensional model, tourismcompanies, customer satisfaction

JEL klasifik acija: L22, L83, Z31

\section{Višedimenzionalni \\ pristup analizi \\ percipirane vrednosti u turizmu}

Sažetak: Ključ za ostvarenje poslovnih ciljeva bazira se na shvatanju i razumevanju načina kako potrošači percipiraju uslužnu ponudu i na istraživanju elemenata koji determinišu satisfakciju i lojalnost korisnika us luga. Savremena turistička preduzećamoraju se fokusirati na stvaranje $\mathrm{i}$ isporuku vrednosti za svoje korisnike usluga kao značajnom izvoru konkurentske prednosti. Cilj rada je identifikacija dimenzija vrednosti uslužne ponude turističkih agencija kod kojih se javljaju značajne razlike u ocenama ispitanika ženskog i muš kog pola. Da bi se is punili ciljevi istraživanja, korišćen je t-test za dva nezavisna uzorka. Sprovedeno je terensko is traživanje i primarni podaci su prikupljeni metodom ankete. Ovaj rad nastojida ukaže da je vrednost za korisnike us luga s ložen i višedimenzionalan koncept. Turis tičke us luge se mogu bolje shvatiti i razumeti ako se analiziraju kroz viš edimenzionalan pristup vrednosti, jer korisnici turističkih usluga mogu u is to vreme doživeti i uživati u funkcionalnim, društvenim, emotivnim i drugim faktorima. U radu su prikazani različiti pristupi analizi percipirane vrednosti koji su prisutni u svetskoj marketing literaturi i koji predstavljaju osnovu za koncipiranje budućih istraživanja.

* topalovicsneza@gmail.com 
Topalović, S., Marinković, $V$. - A multidimensional approach to the analysis of perceived value in tourism Hotel and Tourism Management, 2020, Vol. 8, No. 1: 49-58.

Ključne reči: percipirana vrednost, dimenzije vrednosti, viš edimenzionalni model, turis tička preduzeća, satis fakcija korisnika

JEL klasifik acija: L22, L83, Z31

\section{Introduction}

Touris mas a service industry requires understanding the needs, attitudes, expectations and preferences of service users in order to create a tourist offer better than competitors, as a starting point for a successful marketing concept. From the aspect of tourism sector development, enterprises should strive to ensure the quality level of touris m services as a whole, as this is the only way to meet the needs and expectations of users and achieve positive business performance of enterprises in meeting tourism needs (Ambroso, 2001, p. 30).

The basis of marketing business orientation is based on providing services in accordance with the users' needs and attitudes. Over time, competition directs the organization to provide a higher degree of customer orientation. Consumer orientation is a way of doing business, with activities and business decision making focusing on value for consumers and their satis faction (Barry \& Eric, 2012, p. 9). Consumers need to be at the centre of marketing research, because this is the only way to achieve mutual satisfaction (for the consumer and the company). Tourism companies must treat consumers as direct partners. The level of efficiency that will be achieved through the implementation of consumer marketing depends on the extent to which the service organization will research and identify the needs and expectations of the target group of consumers, define and ultimately implement the marketing strategy of attracting and retaining consumers. The main objective of conducting all marketing activities in touris mis to provide the expected value to con sumers and make a profit in the long run. By creating adequate value for customers, touris m companies create satisfied and loyal consumers, who represent one of the outputs of successful marketing application.

It used to be understood that value is measured by utility for consumers. It is emphasized today that value represents consumers' perceptions of what they receive and what they give (benefits and sacrifices). In recent years, many research papers have viewed value for consumers as a multidimensional concept that incorporates more elements of benefit and sacrifice. The aim of this paper is to point out the various multidimensional models of perceived value that are present in the world literature in the field of tourism.

In order to identify statistically significant differences in the estimation of the values of travel agency services between women and men, a survey was conducted on a sample of 149 res pondents. Primary data were collected through a survey method, and t-test was used in the data analy sis for two independent samples. The significance of the research is reflected in identifying the dimensions of values of travel agency services, which are the drivers of satisfaction and loy alty of their users. These are dimensions that relate to the functionality, economic, emotional and social component of the values of tourist services.

\section{The perceived value concept and the specifics of the concept}

There is no one commonly accepted definition of perceived value in the contemporary literature. The reas on lies in the fact that value as a term is a subjectivecategory, determined by consumers and specific to each individual. A number of authors share the opinion that value to the consumer is the consumer's subjective as sessment of the benefits and costs incurred in purchasing and/or using the products and services (Keränen \& Jalkala, 2013; Lindgreen \& Wynstra, 2005; Woodruff, 1997). The authors Tan and Xu (2015) define 50 
consumer value as an overall as sessment of the utility of a product or service, after the consumer has paid for and purchased the product or service. One of the most accurate and commonly used definitions of value for consumers is the definition given by Holbrook (1999) and by this definition, valuefor consumers is the difference between the benefits a consumer obtain sy buying and using products and services, and the sacrifices related to the investments during the purchasing and use.

When looking at the tourism sector, Sanchez et al. (2006, p. 396) refer to the perceived experience of buying and consuming tourisms ervices as a consumer value. Value for users of tourism services is a function of three elements (Voss et al., 2008, p. 249):

$$
\mathrm{Vt}=\boldsymbol{f}\left(\left(\sum \mathrm{S}, \mathrm{Ef}\right) / \mathrm{Rc}\right)
$$

where:

$\mathbf{V t}-$ is the value for users of touris m services

$\sum \mathbf{S}-$ a set of different services

$\mathbf{E f}$ - experiential factor

Rc-sacrifices

The set of different services $\left(\sum \mathbf{S}\right)$ as an element of the value function for touris ts plays an essential role in value creation. During the travel, tourists have at their dis posal a number of different services that they can consume (transportation, accommodation, food, drinks, gym, swimming pool, massages, sports fields, etc.) affecting directly proportional to the value created for the tourists. The experiential factor $(\mathbf{F})$ as part of the value for the users of tourist services is considered as the most important element of value created and delivered. Touris mexperience is central to the value creation process for service users. It represents the hedonistic value that arises as a result of emotional satisfaction in the process of using tourist services. Sacrifices $(\mathbf{R c})$ as a third element of value for users of touris ms ervices include the financial investment, phy sical and mental effort necessary to purchase products or services, as well as to gather information to make a travel decision, and various types of risk when making a decision (psychological, economic, social).

The multidimensional model starts from the realization that perceived value is a complex concept formed by a number of interrelated dimensions. A number of authors point out that the perceived benefit should be viewed as a combination of phy sical characteris tics, service characteristics, technical support, competence, experience and social benefits (Bolton \& Drew, 1991; Walter, 2006).

During the 1990s, the formulation of the concept of value for consumers took on a utilitarian and hedonic dimension (Babin et al., 1994). The utilitarian value is the value derived from a product and/or service that helps the consumer accomplis h a task, while the hedonic value is an instant gratification that results from performing an activity (Barry \& Eric, 2012, p. 28). By using a product and/or service, consumers seek not only to meet functional needs, but also to meet hedonic needs. Every consumer strives to enjoy and feel comfortable and satisfied during and after consuming a product/service. The aes thetic characteristics of the product play a major role in creating hedonic value (Maričić \& Đorđević, 2012, p. 23). The hedonic dimen sion of value is of utmost importance when consuming s ervices. In the service sector, due to the intan gibility of services, consumers can only have a pleasant or unpleas ant experience during and after using the services.

The authors Babin and Kim(2001) introduced a specific multidimensional conception of value based on the utilitarian and hedonic dimensions in the tourism literature. Tourists use transportation, lodging, food and drink and other services to meet their needs. Likewise, 
tourists want and expect to feel comfortable while us ing transportation, food and drink, lodging, exploring cultural and historical monuments, new places, etc. The best experiences are for the consumer when both high utilitarian and high hedonic value are provided. The study of the utilitarian and hedonic dimension of value provided the basis for further exploration of the multidimensional nature of the concept of value for consumers.

Holbook's ty pology of value for consumers is the approach that has contributed most to the study and interpretation of the concept and nature of value for consumers and to understanding the process of its creation. Holbrook's (1999) typology of value to consumers is based on three dichotomies: extrinsic versus intrinsic value; pers onally oriented value versus value oriented towards others; active versus reactive value, the combination of which highlights eight different dimensions of value: Efficiency - Assessment of Functional Benefits for Investment; Superiority - Product Quality; Status - Product Impact on Status; Affiliation - Features Indicating Membership in a Social Group; Play - a sense of fun and enjoyment through various activities; Aesthetics - a sense of belonging in the use of products based on product design; Ethics - a sense of utility for society based on the use of products; Spirituality-a sense of personal satisfaction through the excitement experienced using the product.

Numerous authors have emphasized the different dimensions of value for consumers. We can identify the exis tence of three dimensions of value: cognitive value, emotional value and retention value (Gummesson, 2008, p. 264). The cognitive value involves the objective and rational perception of consumers on price, quality and convenience. The emotional value refers to the subjective and irrational consumer perception of a business, while retention value includes the number of repeated purchases made by consumers. Consumer value can also be viewed through the following three dimensions: economic value, functional and psychological value (Gupta \& Lehmann, 2006, p. 116). The economic value implies that the consumer will pay less for a given product or service than it would be thecase for competing products or services. The functional value refers to the characteristics and performance of the product. Unlike psychological, the previous two values are characterized by tangibility, that is, values that can be recognized on the basis of tangible attributes. The psychological value is a value that is based on intangible attributes and implies reputation, image of the company, etc.

\section{Key dimensions of value in tourism services}

Due to the complexity in unders tanding the value of services, over time, the authors have put in place models that give insight into the dimensions that affect the value of tourismservices. In the foreign literature, fewer studies belong to the multidimensional, as opposed to the onedimensional, approach.

One of the first multidimens ional models of value, the so-called PERVAL model, pointed to the existence of four dimensions that describe value (Sweeney \& Soutar, 2001):

- Quality;

- Price;

- Emotional value;

- Social value.

At the heart of the PERVAL model is the hedonistic and utilitarian dimension of value. This model also includes the socialdimension of value that occurs in other studies (Gallarza et al., 2016; Leroi-Werelds et al., 2014). Social value is such a dimension of value that relates to an 
image that is determined by the influence of members of the community from the environment.

In the field of hospitality industry, a five-dimensional service value model, known as the SERV-PERVAL model, has been developed (Petrick, 2002). The model draws attention to the following dimensions of service value:

- Quality;

- Price;

- Emotional response;

- Efforts made;

- Reputation.

Compared to PERVAL, this modelstands out for its reputation as a significant part of the values of services that customers in touris mevaluate. The reputation of tourismcompanies is first as sociated with the level of quality in service delivery. In addition, trust, commitment, communication by staff are crucial to building reputation (Wathne et al., 2001, p. 60). Although the SERV-PERVAL model was first applied in the field of touris $\mathrm{m}$, it als o showed its importance in other service industries.

Based on Petrick's model, a model was designed to meas ure the value of a service offering in the hotel industry across three dimensions (Nasution \& Mavondo, 2008):

- Reputation;

- Prestige;

- Price.

Nasution and Mavondo cite prestige as one of the key dimensions of value for tourism service users. Prestige is treated as a component of the social value perceived by users under the influence of an environment whose opinion is valid with respect to bu sinesses that have a built in status symbol (Bergami \& Bagozzi, 2000).

In the context of travel agency services, a GLOVAL model has been developed, which emphasizes that the value of a service consists of six dimensions (Sanchez et al., 2006). According to the authors mentioned, value is a six-dimensional concept that encompasses four dimensions of a functional nature and two affective dimensions:

- Interior and exterior of the tourist agency;

- Quality of service offer;

- Expertise of employees;

- Price;

- Emotional value;

- Social value.

The GLOVAL model emphasizes employee expertise as a significant dimension of the value of services in travel agencies. This dimension is crucial especially in the service sector, where it is difficult for cus tomers to evaluate services before making a purchase. In as sessing the total value, users of touris ms ervices pay attention to the competence, understanding and commitment of the service staff. Touris m service users expect the staff to be proficient in providing relevant information about the services, as well as in showing interest in meeting their demands and the like.

Drawing on Holbook's typology of values, reviewing empirical studies, Gallarza and Gil (2008) highlight the following dimensions of value that tourists experience while using tourist services: 
- Efficiency;

- Quality;

- Play;

- Aesthetics;

- Social value.

The functional part of the value is reflected in efficiency in terms of convenience and quality of tourist services provided, whereas the emotional value is illus trated by playing as a sense of fun and enjoyment in various activities and aesthetics as a beauty that tourists appreciate while visiting a particular destination.

\section{Methodology and results of empirical research}

In order to determine differences in perceptions of different dimensions of values by female and male respondents, an empirical study was conducted using survey methods. The sample included a total of 149 respondents, with female respondents accounting for about 58\% (86) and male for about $42 \%$ of the total sample (63).

The study involved respondents travelling through four travel agencies operating in the territory of the Republic of Serbia. The survey was conducted in the period February and April 2019. The surveys were submitted by tourist guides just before the travels realized.

The perceived value of the services was measured over 12 statements that reflect the most significant dimensions of the value of the travel agencies' service offer (functional, economic, emotional and social value). The statements are adapted on the basis of the relevant foreign studies (Floh et al., 2014; Roig et al., 2009). The res pondents rated the given findings on a seven-point Likert scale (1 - I absolutely disagree with the statement; 7 - I absolutely agree with the statement).

Using the $t$-test for two independent samples, it was examined whether statistically significant differences in the average ratings of the value of travel agency services between the two groups of respondents (women and men) occur. The analys is of the collected data was implemented in the statistical package SPSS 20.

Table 1: The results of the t-test

\begin{tabular}{|c|l|c|c|c|c|}
\hline No. & \multicolumn{1}{|c|}{ Statements } & $\begin{array}{c}\text { Sample } \\
\text { M (SD) }\end{array}$ & $\begin{array}{c}\text { Female } \\
\text { M (SD) }\end{array}$ & $\begin{array}{c}\text { Male } \\
\text { M (SD) }\end{array}$ & $\begin{array}{c}\text { t- } \\
\text { statistics }\end{array}$ \\
\hline 1 & $\begin{array}{l}\text { My travel agency is a reliable } \\
\text { travel agency }\end{array}$ & $5.92(1.069)$ & $6.05(1.073)$ & $5.75(1.047)$ & $1.706^{*}$ \\
\hline 2 & $\begin{array}{l}\text { My travel agency offers high } \\
\text { quality services compared to } \\
\text { the competition }\end{array}$ & $5.60(1.108)$ & $5.74(1.087)$ & $5.41(1.116)$ & $1.818^{*}$ \\
\hline 3 & $\begin{array}{l}\text { The employees do their job } \\
\text { profes sionally }\end{array}$ & $5.95(1.187)$ & $5.99(1.213)$ & $5.90(1.160)$ & 0.423 \\
\hline 4 & $\begin{array}{l}\text { My travel agency offers } \\
\text { adequate value for money } \\
\text { invested }\end{array}$ & $5.71(1.135)$ & $5.84(1.050)$ & $5.54(1.229)$ & 1.551 \\
\hline 5 & $\begin{array}{l}\text { The price of travel agency } \\
\text { services is more favourable } \\
\text { than the prices of other travel } \\
\text { agencies }\end{array}$ & $5.62(1.195)$ & $5.83(1.180)$ & $5.33(1.164)$ & $2.530^{* *}$ \\
\hline 6 & $\begin{array}{l}\text { The price of travel agency } \\
\text { service justifies my investment }\end{array}$ & $5.94(0.974)$ & $6.17(0.843)$ & $5.62(1.054)$ & $3.452^{* *}$ \\
\hline \hline
\end{tabular}


Topalović, S., Marinković, V. -A multidimensional approach to the analysis of perceived value in tourism Hotel and Tourism Management, 2020, Vol. 8, No. 1: 49-58.

\begin{tabular}{|c|l|l|l|l|l|}
\hline & $\begin{array}{l}\text { (time, physical and mental } \\
\text { effort) }\end{array}$ & & & \\
\hline 7 & $\begin{array}{l}\text { I have a good feeling when } \\
\text { using the travelagency services }\end{array}$ & $5.80(1.168)$ & $5.90(1.085)$ & $5.67(1.270)$ & 1.154 \\
\hline 8 & $\begin{array}{l}\text { Using the services of the travel } \\
\text { agency gives me a sense of } \\
\text { satisfaction }\end{array}$ & $5.65(1.139)$ & $5.84(1.126)$ & $5.40(1.115)$ & $2.368^{* *}$ \\
\hline 9 & $\begin{array}{l}\text { I feel relaxed while using the } \\
\text { travel agency services }\end{array}$ & $5.70(1.143)$ & $5.87(1.115)$ & $5.46(1.148)$ & $2.220^{* *}$ \\
\hline 10 & $\begin{array}{l}\text { My travelagency has a built-in } \\
\text { reputation }\end{array}$ & $5.68(1.411)$ & $5.93(1.235)$ & $5.33(1.566)$ & $2.508^{* *}$ \\
\hline 11 & $\begin{array}{l}\text { Using the services of the travel } \\
\text { agency I leave a good } \\
\text { impres sion on the people I } \\
\text { know }\end{array}$ & $5.51(1.354)$ & $5.85(1.122)$ & $5.05(1.507)$ & $3.558^{* *}$ \\
\hline 12 & $\begin{array}{l}\text { Using the services of the travel } \\
\text { agency makes me feel like a } \\
\text { socially acceptable pers on }\end{array}$ & $5.27(1.446)$ & $5.55(1.262)$ & $4.89(1.597)$ & $2.707^{* *}$ \\
\hline
\end{tabular}

* The difference in the mean values is significant at the level of $0.1 ; * *$ The difference in the means is significant at the 0.05 level; $\mathrm{M}$ - arithmetic mean; SD - standard deviation.

Source: Author's research

Table 1 shows the results of the $t$-test for two independent samples. The res pondents' views for the observed segments differ significantly in the case of 9 out of the 12 statements. It can be observed that the res pondents gave the highest average grade to the statement "Employees do their job profes sionally" $(M=5.95)$; "My travel agency is a reliable travel agency" $(M=$ 5.92), which belong to the functional dimension of value, as well as to the statement "The price of the travel agency service justifies my inves tment (time, physical and mental effort)" $(M=5.94)$ which reflects the economic dimension of perceived value. With this statement, the highest degree of homogeneity of the respondents' attitudes was expres sed (SD $=0.974)$.

\section{Discussion and conclusion}

The focus of the paper is the importance of a multidimensional approach to the analysis of perceived value in touris m. Some multidimensional models for measuring values set by foreign authors are presented. These models allow the identification and analys is of those dimensions of value that stand out as important drivers of customer satisfaction. Based on individual studies conducted, the authors confirm that the value of customer services directly precedes their satisfaction, and as such is considered a major driver of satisfaction (Hu et al., 2009; Lim et al., 2006; Luo et al., 2019). Although service quality has proven to be crucial in providing satisfaction, perceived value as a factor preceding satisfaction is considered to be much more complex, as it involves both cognitive and affective elements (Woodruff, 1997). In the field of touris $m$, the value of services has also been proven to directly precede and influence customer satisfaction (Feng \& Morrison, 2007; Williams et al., 2017). Value through satisfaction influences the consumer to participate in re-purchasing. Consumer valuation based on previous experiences will influence his/her decision to make a repeat purchase in the future at the same manufacturer and be prepared to make a positive impression on others (Bolton et al., 2000).

The empirical research conducted confirms that the res pondents are moderately satis fied with the value of the services provided by the travel agencies, with the highest rating given to the 
service staff and their professionalism, as confirmed in previous studies. The statement "Using the services of the travel agency makes me feel socially acceptable" was rated the lowest. This result is a guideline for owners to invest more money in building a brand. Furthermore, out of the 12 statements, only three did not show significant differences in the attitudes of women and men.

Identifying the key dimensions of value for tourism services enables the creation and delivery of adequate value for cus tomers. This encourages the use of touris m services in the future, builds satisfied customers, who over time become loyal to the services of a particular company. Modern tourismcompanies are increasingly realizing that the value of customer service is a key indicator of strategic management. Value creation becomes an imperative in businessand a source of maintaining an edge over competition. Busines ses must focus all their marketing activities on creating and es tablis hing satisfied and loyal customers that are key to achieving long-term profitability. It is imperative that each tourismcompany identifies the key dimensions of value for services as drivers of loyalty of its users and continue to improve relationships with them.

The research conducted has several limitations. The study was conducted for a limited period of time, thus, in the future, it would be advisable to conduct research that will be performed at multiple intervals. This would identify changes in respondents' attitudes and provide a more detailed analysis. The analys is is limited to a certain number of findings, so it is recommended to include in the next research a larger number of findings that describe the key dimens ions of the values of service offer of travel agencies. It would also be interesting to compare male and female respondents' views on other demographic characteristics.

\section{References}

1. Ambroso, O. (2001). Customer Relationship Marketing. Italia: Etas.

2. Babin, B. J., Darden, W. R., \& Griffin, M. (1994). Work and/or fun: Measuring hedonic and utilitarian shopping. Journal of Consumer Research, 20(4), 644-656.

3. Babin, B. J., \& Kim, K. (2001). International students travel behavior: A model of the travel-related consumer/dissatisfaction process. Journal of Travel and Tourism Marketing, 10(1), 93-106. https://doi.org/10.1300/J073v10n01_06

4. Barry J. B., \& Eric, G. H. (2012). Ponašanje potrošača [Consumer behavior]. Beograd: Data Status.

5. Bergami, M., \& Bagozzi, R. P. (2000). Self-categorization, affective commitment and group self-esteem as distinct of social identity in the organization. British Journal of Social Psychology, 39(4), 555-577. https://doi.org/10.1348/014466600164633

6. Bolton, R. N., \& Drew, J. H. (1991). A multis tage modelof customers' as ses sments of service quality and value. Journal of Consumer Research, 17(4), 375-384.

7. Bolton, R., Kannan, P., \& Bramlett, M. (2000). Implications of loyalty program membership and service experiences for customer retention and value. Journal of the Academy of Marketing Science, 28(1), 95-108. https ://doi.org/10.1177/0092070300281009

8. Feng, R., \& Morrison, A. M. (2007). Quality and value networks: Marketing travel clubs. Annals of Tourism Research, 34(3), 588-609. https://doi.org/10.1016/j.annals.2007.01.006

9. Floh, A., Zauner, A., Koller, M., \& Rusch, T. (2014). Customer segmentation using unobserved heterogeneity in the perceived-value-loyalty-intentions link. Journal of Business Research, 67(5), 974-982. https://doi.org/10.1016/j.jbusres.2013.08.003 
10. Gallarza, M. G., \& Gil, I. (2008). The concept of value and its dimensions: A tool for analysing tourism experiences. Tourism Review, 63(3), 4-20. https://doi.org/10.1108/16605370810901553

11. Gallarza, M. G., Eugenia R. M. \& Gil, I. (2016). Stretching the value-satisfactionloyalty chain by adding value dimensions and cognitive and affective satisfactions. Management Decision, 54(4), 981-1003. https://doi.org/10.1108/MD-07-2015-0323

12. Gummess on, E. (2008). Total Relationship Marketing. Ams terdam: Elsevier.

13. Gupta, S., \& Lehmann, D. (2006). Managing customers as investments. New Jersey: Pears on Education.

14. Holbrook, M. (1999). Consumer Value: A framework for analysis and research. London: Routledge.

15. Hu, H., Kandampully, J., \& Juwaheer, D. T. (2009). Relationships and impacts of service quality, perceived value, customer satisfaction, and image: An empirical study. The Service Industries Journal, 29(2), 111-122. https://doi.org/10.1080/02642060802292932

16. Keränen, J., \& Jalkala, A. (2013). Towards a framework of cus tomer value assess ment in B2B markets: An exploratory study. Industrial Marketing Management, 42(8), 13071317. https://doi.org/10.1016/j.indmarman.2013.06.010

17. Leroi-Werelds, S., Streukens, S., Brady, M. K., \& Swinnen, G. (2014). Assessing the value of commonly used methods for measuring customer value: A multi-setting empirical study. Journal of the Academy of Marketing Science, 42(4), 430-451. https://doi.org/10.1007/s 11747-013-0363-4

18. Lim, H., Widdows, R., \& Park, J. (2006). M-loyalty: Winning strategies for mobile carriers. Journal of Consumer Marketing, 23(4), 208-218. https://doi.org/10.1108/07363760610674338

19. Lindgreen, A., \& Wynstra, F. (2005). Value in business markets: What do we know? Where are we going?. Industrial Marketing Management, 34(7), 732-748. https ://doi.org/10.1016/j.indmarman.2005.01.001

20. Luo, Y., Wang, W., \& Sakura, W. (2019). Factors affecting service innovation, customer value toward customer satisfaction: Case on health care industry. Revista de Cercetare si Interventie Sociala, 64, 213-222. https ://doi.org/10.33788/rcis.64.17

21. Maričić, B., \& Đorđević, A. (2012). Kreiranje i isporučivanje vrednosti potrošačima [Creating and delivering value to consumers]. Beograd: CID, Ekonomski fakultet.

22. Nasution, H. N., \& Mavondo,F. T. (2008). Customervalue in the hotel industry: What managers believe they deliver and what customer experience. International Journal of Hospitality Management, 27, 204-213. https ://doi.org/10.1016/j.ijhm.2007.02.003

23. Petrick, J. F. (2002). Development of a multi-dimensional scale for measuring the perceived value a service. Journal of Leisure Research, 34(2), 119-134.

24. Roig, J. C. F., Garcia, J. S., \& Tena, M. A. M. (2009). Perceived value and customer loyalty in financial services. The Service Industries Journal, 29(6), 775-789. https://doi.org/10.1080/02642060902749286

25. Sanchez, J., Callaris a, L., Rodriguez, R. M., \& Moliner, M. A. (2006). Perceived value of the purchase of a tourism product. Tourism Management, 27(3), 394-409. https://doi.org/10.1016/j.tourman.2004.11.007

26. Sweeney, J. C., \& Soutar, G. N. (2001). Consumer perceived value: The development of a multiple item scale. Journal of Retailing, 77(2), 203-220. https://doi.org/10.1016/S0022-4359(01)00041-0

27. Tan, L., \& Xu, S. (2015). Research on the mode of enterprise service innovation in micro era. International Journal of u-and e-Service, Science and Technology, 8(11), 199-210. https://doi.org/10.14257/ijunesst.2015.8.11.20 
28. Voss C., Roth A., \& Chase R. (2008). Experience, service operations strategy, and services as destinations: Foundations and exploratory investigation. Production and Operations Management, 17(3), 247-266. https ://doi.org/10.3401/poms .1080.0030

29. Walter, D. (2006). Demand chain effectiveness - supply chain efficiencies: A role for enterpris e information management. Journal of Enterprise Information Management, 19(3), 246-261. https://doi.org/10.1108/17410390610658441

30. Wathne, K., Biong, H., \& Heide, J. (2001). Choice of supplier in embedded markets: Relationship and marketing program effects. Journal of Marketing, 65(2), 54-66. https://doi.org/10.1509/.jmkg.65.2.54.18254

31. Williams, P., Soutar, G., Ashill, N., \& Naumann, E. (2017). Value drivers and adventure touris m: A comparative analy sis of Japanese and Western consumers. Journal of Service Theory and Practice, 27(1), 102-122. https://doi.org/10.1108/JSTP-05-2015-0116

32. Woodruff, R. B. (1997). Customer value: The next source for competitive advantage. Journal of the Academy of Marketing Science, 25(2), 139-153. http://dx.doi.org/10.1007/BF02894350 